Article

\title{
Optimal Regimen of N-Acetylcysteine on Chromium-Induced Renal Cell Damage
}

\author{
I-Jeng Yeh ${ }^{1} \oplus$, Tzu-Yi Wang ${ }^{1}$, Jhong-Ching Lin ${ }^{1}$, Tzeng-Jih Lin ${ }^{2}$, Jung-San Chang ${ }^{3,4} \oplus$, \\ Meng-Chi Yen ${ }^{1,5}{ }^{D}$, Yao-Hua Liu ${ }^{1}$, Pei-Lin $W_{u}{ }^{1}$, Fen-Wei Chen ${ }^{1}$, Yueh-Lun Shih ${ }^{1}$ and \\ Chiung-Yu Peng 6,7,* \\ 1 Department of Emergency Medicine, Kaohsiung Medical University Hospital, \\ Kaohsiung Medical University, Kaohsiung 807, Taiwan \\ 2 Family Medicine Department, Taoyuan Branch, Taipei Veterans General Hospital, Taipei 112, Taiwan \\ 3 Department of Renal Care, College of Medicine, Kaohsiung Medical University, Kaohsiung 807, Taiwan \\ 4 Division of Gastroenterology, Department of Internal Medicine, Kaohsiung Medical University Hospital, \\ Kaohsiung Medical University, Kaohsiung 807, Taiwan \\ 5 Graduate Institute of Clinical Medicine, College of Medicine, Kaohsiung Medical University, \\ Kaohsiung 807, Taiwan \\ 6 Department of Public Health, College of Health Science, Kaohsiung Medical University, \\ Kaohsiung 807, Taiwan \\ 7 Research Center for Environmental Medicine, Kaohsiung Medical University, Kaohsiung 807, Taiwan \\ * Correspondence: pengcy@kmu.edu.tw; Tel.: +886-312-1101 (ext. 2141 \#39)
}

Received: 24 July 2019; Accepted: 26 August 2019; Published: 28 August 2019

check for updates

\begin{abstract}
Chromium (Cr) is a well-known heavy metal that can cause renal damage. The production of reactive oxygen species (ROS) due to chromium-induced toxicity induces cell dysfunction, apoptosis, and death. N-acetylcysteine (NAC) is an antioxidant used as an antidote for chromium-induced toxicity. However, the optimal regimen and protective mechanisms of NAC are not fully understood in human renal cells. Our results showed that exposure to $10 \mu \mathrm{M} \mathrm{K}_{2} \mathrm{Cr}_{2} \mathrm{O}_{7}$, a toxic $\mathrm{Cr}(\mathrm{VI})$ compound, induced apoptosis and production of intracellular ROS in the human proximal tubular epithelial cell line HK-2. Supplements of 600 or $1000 \mu \mathrm{g} / \mathrm{mL}$ NAC inhibited intracellular ROS in HK-2 cells exposed to $\mathrm{Cr}(\mathrm{VI})$ and significantly increased cell viability within $2 \mathrm{~h}$ of $\mathrm{Cr}(\mathrm{VI})$-induced cytotoxicity. Moreover, $\mathrm{Cr}(\mathrm{VI})$ induced the expression of apoptosis markers, including cleaved-caspase-3, cleaved-poly (ADP-ribose) polymerase, cleaved-caspase 8, and cleaved-caspase 9 , and altered the expression ratio of Bax/Bcl-xL. Expression of apoptosis markers within $2 \mathrm{~h}$ of $\mathrm{Cr}(\mathrm{VI})$-induced cytotoxicity in cells treated with $600 \mu \mathrm{g} / \mathrm{mL}$ NAC was significantly suppressed. However, delayed treatment with NAC at $4 \mathrm{~h}$ and $8 \mathrm{~h}$ after exposure to $\mathrm{Cr}$ did not suppress the activation of apoptotic pathways. In summary, our study reports the optimum timing and dose of NAC for the protection of human renal proximal tubular cells from $\mathrm{Cr}(\mathrm{VI})$-induced cell death. The NAC treatment strategy described could be applied in clinical practice to suppress renal cell apoptosis, which in turn could rescue renal function.
\end{abstract}

Keywords: apoptosis; hexavalent chromium; human proximal tubular epithelial cell; $\mathrm{N}$-acetylcysteine (NAC), reactive oxygen species

\section{Introduction}

Chromium (Cr) is an abundant element in the Earth's crust. Trivalent $\mathrm{Cr}(\mathrm{III})$ and hexavalent $\mathrm{Cr}(\mathrm{VI})$ are the two most stable oxidative states of $\mathrm{Cr}$ in the natural environment. Compared to $\mathrm{Cr}$ (III), $\mathrm{Cr}(\mathrm{VI})$ is more cytotoxic because it can be absorbed by cells, which induces the production of reactive oxygen species (ROS) [1-3]. Cr(VI) has been detected in samples from various sources of water [4,5]. In addition, $\mathrm{Cr}(\mathrm{VI})$ exposure causes breaks in DNA strands in several types of mammalian cells [6-8]. 
Therefore, consuming $\mathrm{Cr}(\mathrm{VI})$-contaminated water might be a risk factor for cancer development. $\mathrm{Cr}(\mathrm{VI})$ causes the disruption of metabolic regulation between carbohydrates and proteins in murine renal tissue [9]. Furthermore, common industrial applications of $\mathrm{Cr}(\mathrm{VI})$ increase the risk of acute occupational exposure to $\mathrm{Cr}(\mathrm{VI})$, which can lead to severe destruction of proximal renal tubular cells, resulting in significant deterioration of renal function in humans [10-14]. To manage the acute toxic effects of $\mathrm{Cr}(\mathrm{VI})$, hemodialysis [10], hemoperfusion [11], exchange transfusion [12,13], and peritoneal dialysis [14] were implemented in several clinical cases; however, these treatments did not provide any beneficial outcomes. Therefore, the development of an alternative and optimal strategy to manage the acute toxic effects of $\mathrm{Cr}(\mathrm{VI})$ remains an urgent issue.

When $\mathrm{Cr}(\mathrm{VI})$ is absorbed into cells it is rapidly reduced, subsequently resulting in the production of several reactive chromium intermediates, such as $\mathrm{Cr}(\mathrm{IV})$ and $\mathrm{Cr}(\mathrm{V})$, as well as ROS. All of these intermediates and molecules are considered to be responsible for altering the normal functions of cells and promoting apoptosis $[15,16]$. Based on its heavy metal properties and the oxidative stress it causes in cells, multiple chelating agents and antioxidant remedies have been proposed to rescue acute Cr-induced toxicity. Our recent study showed that an optimized dose of an antioxidant, L-ascorbic acid, protected human kidney cells from apoptosis [17]. N-acetylcysteine (NAC), a potent antioxidant remedy, has been safely and widely used to manage oxidative stress injury [18]. However, the mechanisms for cell rescue against the toxic effects of $\mathrm{Cr}$ have not yet been clearly elucidated. Because glutathione is a major endogenous antioxidant used for ROS elimination, and the absence of L-cysteine limits glutathione synthesis [19,20], the NAC-mediated protective effect on Cr toxicity might be due to the stimulation of glutathione synthesis [21-23]. In addition, NAC has been demonstrated as a chelator of some heavy metals, including lead, mercury, cadmium, and Cr [24]. Treatment of NAC via intraperitoneal injection could protect the kidneys and liver from $\mathrm{Cr}$-induced oxidative stress in mice [25]. This evidence suggests that NAC could serve as a potential treatment for managing Cr-induced toxicity in clinical settings.

Currently, there is no direct evidence to support the hypothesis that NAC treatment can protect the kidneys against $\mathrm{Cr}$ damage. Furthermore, the regulatory mechanisms of NAC on $\mathrm{Cr}$-induced apoptosis have not been determined in human renal cells. Thus, our study aims to investigate the optimal dosage of NAC, the optimal time-point of treatment after $\mathrm{Cr}$-induced toxicity, the maximum delay-period for NAC to rescue Cr-induced apoptosis, and the possible molecular mechanisms of NAC on Cr-induced apoptosis in an immortalized human proximal tubular epithelial cell line.

\section{Results}

\subsection{Cr(VI)-Induced Toxicity Results in HK-2 Apoptosis}

To evaluate the toxic effects of $\mathrm{Cr}(\mathrm{VI}), \mathrm{HK}-2$ cells were treated with potassium dichromate $\left(\mathrm{K}_{2} \mathrm{Cr}_{2} \mathrm{O}_{7}\right)$ because it is a toxic compound of $\mathrm{Cr}(\mathrm{VI})$ and induces nephrotoxicity in humans and animals [26]. In our previous study, the cell viability of HK-2 significantly decreased after treatment with $10 \mu \mathrm{M}$ of $\mathrm{K}_{2} \mathrm{Cr}_{2} \mathrm{O}_{7}$ [17]. The same concentration $(10 \mu \mathrm{M})$ of $\mathrm{K}_{2} \mathrm{Cr}_{2} \mathrm{O}_{7}$ was used in this study. In Figure 1, the results of Annexin V/propidium iodide (PI) staining showed an increased number of apoptotic cells (Annexin V-positive/PI-negative cells) in $\mathrm{K}_{2} \mathrm{Cr}_{2} \mathrm{O}_{7}$-exposed groups when compared with those in the control group $(0 \mathrm{~h})$. The data indicated that $10 \mu \mathrm{M} \mathrm{K}{ }_{2} \mathrm{Cr}_{2} \mathrm{O}_{7}$ induced apoptosis in the proximal tubular epithelial renal cell line HK-2. 


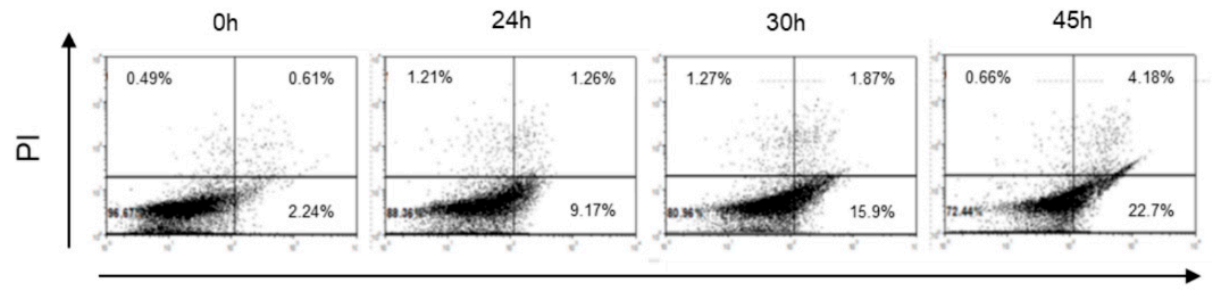

FITC-AnnexinV

Figure 1. $\mathrm{K}_{2} \mathrm{Cr}_{2} \mathrm{O}_{7}$-induced apoptosis in HK-2 cells. Detection of apoptotic cells using Annexin $\mathrm{V} /$ propidium iodide (PI) at 24, 30, and $45 \mathrm{~h}$.

\subsection{NAC Treatment Protects HK-2 from Cr(VI)-Induced ROS}

To evaluate whether NAC induces a toxic effect, HK-2 cells were treated with different concentrations of NAC (from 0 to $1000 \mu \mathrm{g} / \mathrm{mL}$ ). The viability of HK-2 cells was not significantly affected when the NAC concentration was lower than $1000 \mu \mathrm{g} / \mathrm{mL}$ (Figure 2A). Because ROS is a major cause of $\mathrm{Cr}(\mathrm{VI})$-induced nephrotoxicity, the intracellular ROS levels in $\mathrm{Cr}(\mathrm{VI})$-exposed HK-2 were evaluated by $2^{\prime}, 7^{\prime}$-Dichlorofluorescin diacetate (DCFDA) staining. The intracellular ROS levels were significantly higher in $\mathrm{Cr}(\mathrm{VI})$-exposed cells than in control cells. The intracellular ROS levels of HK-2 cells showed a decreasing trend in the 300, 600, and $1000 \mu \mathrm{g} / \mathrm{mL}$ NAC-treated groups (Figure 2B). Moreover, the ROS level was significantly inhibited when the cells were co-treated with 600 and $1000 \mu \mathrm{g} / \mathrm{mL}$ NAC and $10 \mu \mathrm{M}$ of $\mathrm{K}_{2} \mathrm{Cr}_{2} \mathrm{O}_{7}$ (Figure 2C).

A

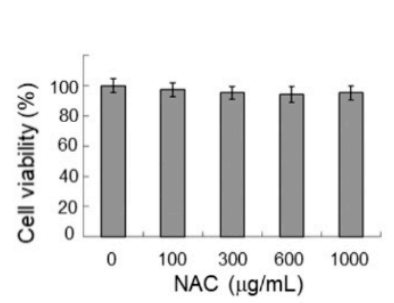

B

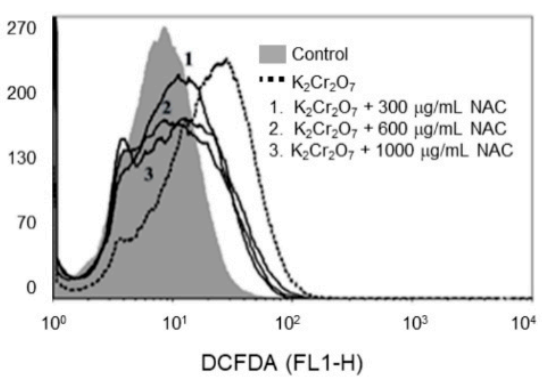

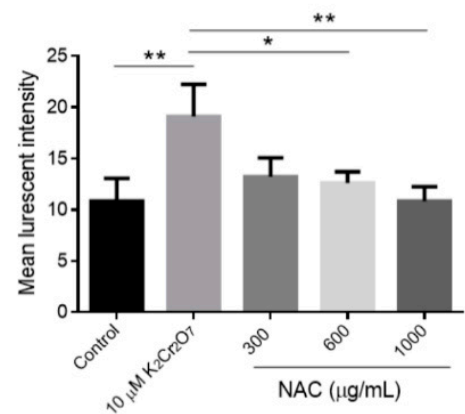

Figure 2. Effect of $\mathrm{N}$-acetylcysteine (NAC) treatment on intracellular reactive oxygen species (ROS) of $\mathrm{K}_{2} \mathrm{Cr}_{2} \mathrm{O}_{7}$-induced cytotoxicity in $\mathrm{HK}-2$ cells. (A) Cell viability at $24 \mathrm{~h}$ after exposure to different concentrations of NAC in HK-2 cells. (B) Detection of ROS levels by flow cytometry with different NAC in $\mathrm{K}_{2} \mathrm{Cr}_{2} \mathrm{O}_{7}$-treated $\mathrm{HK}-2$ cells. The filled gray area indicates the control group and the dashed line indicates the $10 \mu \mathrm{M} \mathrm{K}{ }_{2} \mathrm{Cr}_{2} \mathrm{O}_{7}$-treated group. The numbers 1,2 , and 3 indicate $\mathrm{HK}-2$ cells

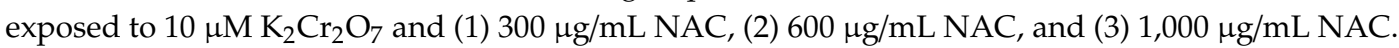
(C) Quantification of ROS levels. Data are presented as mean $\pm \mathrm{SD} .{ }^{*} P<0.05,{ }^{* *} P<0.01$, when compared with the $10 \mu \mathrm{M} \mathrm{K}{ }_{2} \mathrm{Cr}_{2} \mathrm{O}_{7}$-treatment group.

\subsection{NAC Treatment Protects HK-2 from Cr(VI)-Induced Cell Death}

To further evaluate the protective effect of NAC on $\mathrm{K}_{2} \mathrm{Cr}_{2} \mathrm{O}_{7}$-induced toxicity, HK-2 cells was subjected to NAC treatment at different time-points post- $\mathrm{K}_{2} \mathrm{Cr}_{2} \mathrm{O}_{7}$ treatment (from 0 to $8 \mathrm{~h}$ ) and then incubated for a further $36 \mathrm{~h}$ (Figure 3A). In Figure 3B-D, 300, 600, and $1000 \mu \mathrm{g} / \mathrm{mL}$ of NAC treatment significantly enhanced cell viability at 0,1 , and $2 \mathrm{~h}$ post $-\mathrm{K}_{2} \mathrm{Cr}_{2} \mathrm{O}_{7}$ treatment. In contrast, supplementation of NAC at 4 and $8 \mathrm{~h}$ post- $\mathrm{K}_{2} \mathrm{Cr}_{2} \mathrm{O}_{7}$ treatment (Figure $3 \mathrm{E}, \mathrm{F}$ ) had no benefits on the viability of HK-2 cells. The morphologies of NAC- and $\mathrm{K}_{2} \mathrm{Cr}_{2} \mathrm{O}_{7}$-treated HK-2 cells are shown in Figure 4 . The regulation of the apoptotic pathway was examined further. 
A

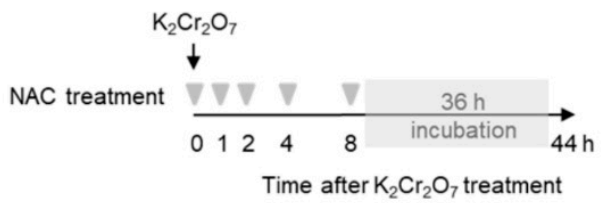

D

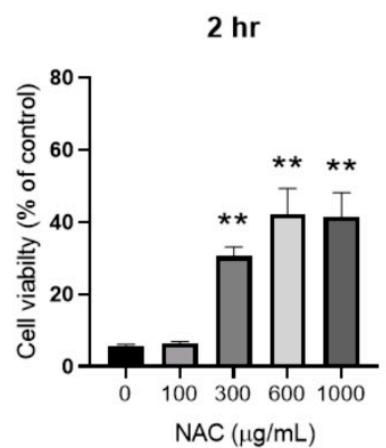

B

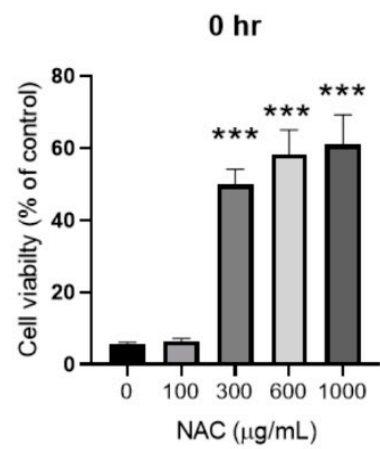

$E$

$4 \mathrm{hr}$

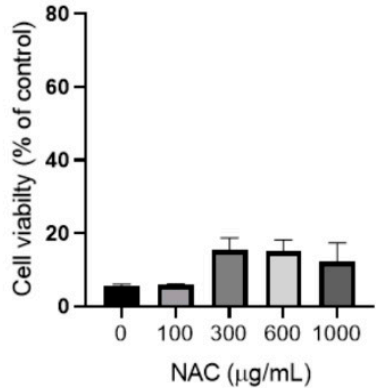

C

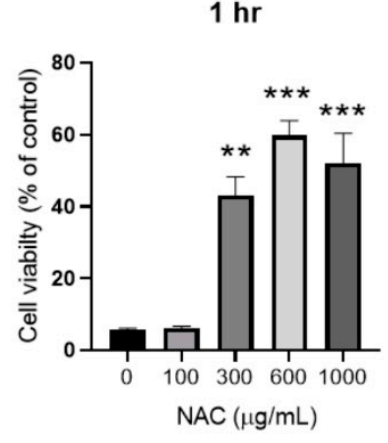

$\mathrm{F}$

Figure 3. Protective effect of NAC on cell viability of HK-2 cells. (A) Scheme of time-delayed NAC treatment. The viability of HK-2 at (B) $0 \mathrm{~h},(\mathbf{C}) 1 \mathrm{~h},(\mathbf{D}) 2 \mathrm{~h},(\mathbf{E}) 4 \mathrm{~h}$, and (F) $8 \mathrm{~h}$ post-treatment with $10 \mu \mathrm{M}$ $\mathrm{K}_{2} \mathrm{Cr}_{2} \mathrm{O}_{7}$ is demonstrated. Data are presented as mean $\pm \mathrm{SD}$. ${ }^{*} P<0.05,{ }^{* *} P<0.01$, and ${ }^{* * *} P<0.001$, when compared with $0 \mathrm{~g} / \mathrm{mL}$ NAC-treated group at each time-point.

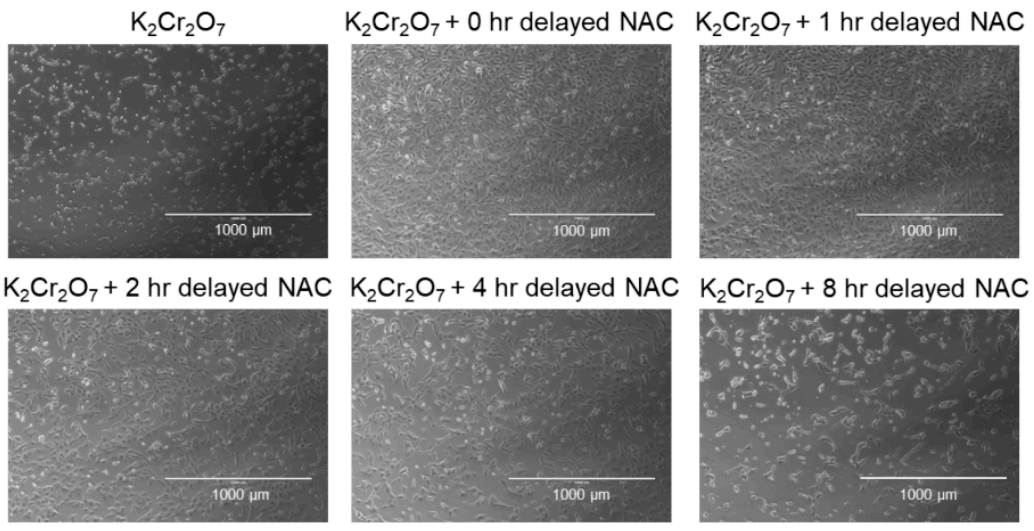

Figure 4. Morphology of HK-2 cells. (A) $10 \mu \mathrm{M} \mathrm{K}{ }_{2} \mathrm{Cr}_{2} \mathrm{O}_{7}$-treated $\mathrm{HK}-2$ cells and $10 \mu \mathrm{M} \mathrm{K}_{2} \mathrm{Cr}_{2} \mathrm{O}_{7}$-treated HK-2 cells with delayed NAC treatment at (B) $0 \mathrm{~h},(\mathbf{C}) 1 \mathrm{~h},(\mathbf{D}) 2 \mathrm{~h},(\mathrm{E}) 4 \mathrm{~h}$, and (F) $8 \mathrm{~h}$.

\subsection{NAC Treatment Altered Cr(VI)-Induced Apoptotic Pathways}

The results of the Western blot assay revealed that expression of apoptotic markers, including cleaved-poly (ADP ribose) polymerase (PARP) and cleaved-caspase 3 was induced after $\mathrm{K}_{2} \mathrm{Cr}_{2} \mathrm{O}_{7}$ exposure (Figure 5), in addition to the ratio of Bax/Bcl-xL and cleaved-caspase 9 expression. In contrast, NAC treatment of HK-2 cells did not significantly induce expression levels of cleaved-PARP and cleaved-caspase 3 compared to those in HK-2 control cells. Since the protective effects of NAC were demonstrated at certain time-points (as depicted in Figures 3 and 4), the statuses of PARP, caspase 3, Bax, Bcl-xL, caspase 9, and caspase 8 were also evaluated at the same time-points. Our results showed that the cleaved-PARP and cleaved-caspase 3 protein levels were almost inhibited at 0 and $2 \mathrm{~h}$ 
post- $\mathrm{K}_{2} \mathrm{Cr}_{2} \mathrm{O}_{7}$ treatment. In addition, a relatively low ratio of $\mathrm{Bax} / \mathrm{Bcl}-\mathrm{xL}$ and inhibition of caspase 9 activaty were observed at 0 and $2 \mathrm{~h}$ post- $\mathrm{K}_{2} \mathrm{Cr}_{2} \mathrm{O}_{7}$-induced toxicity. In contrast, the NAC treatment significantly inhibited the activation of caspase 8 up to $8 \mathrm{~h}$ post- $\mathrm{K}_{2} \mathrm{Cr}_{2} \mathrm{O}_{7}$ treatment (Figure 5E). The summarized graph of the present study is presented in Figure 6.

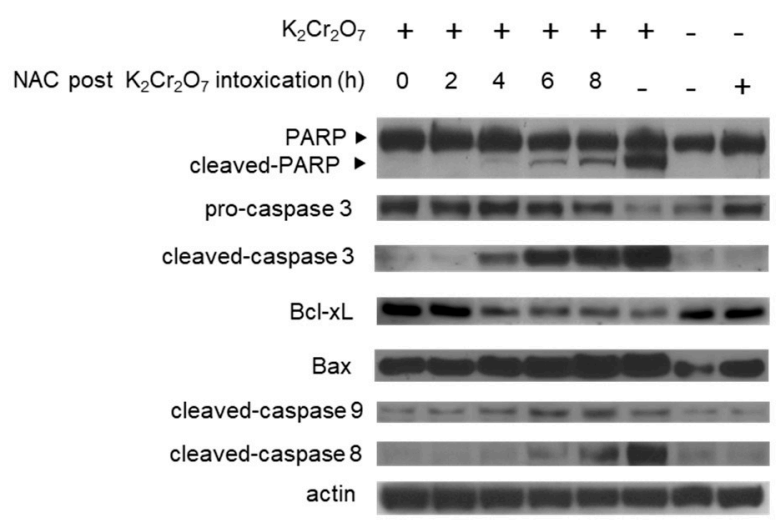

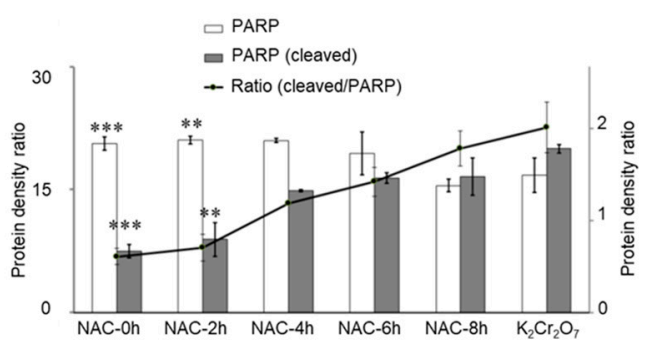

C

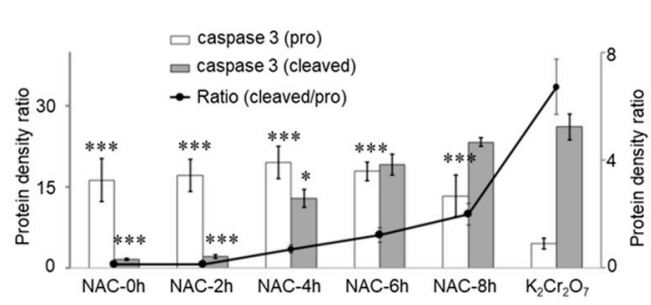

$E$

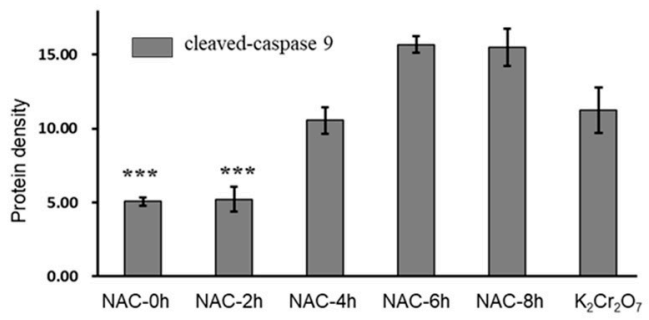

D

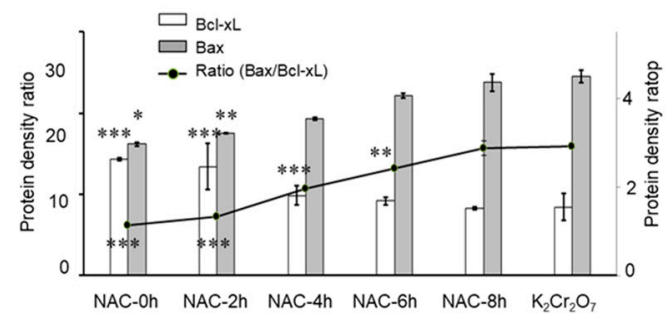

$\mathrm{F}$

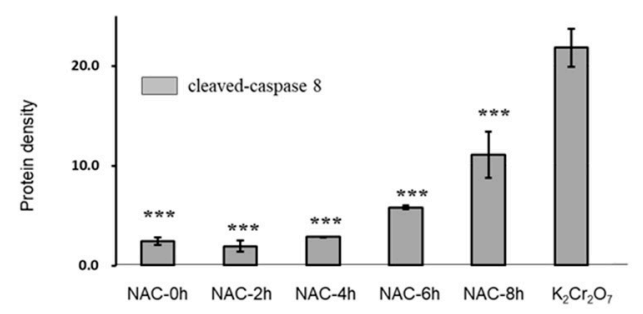

Figure 5. Evaluation of apoptosis signaling pathways. HK-2 cells were first exposed to $10 \mu \mathrm{M} \mathrm{K}_{2} \mathrm{Cr}_{2} \mathrm{O}_{7}$ treatment before being treated with NAC at $0,2,4,6$, and $8 \mathrm{~h}$. Protein lysates were collected after further incubation at $36 \mathrm{~h}$. (A) Evaluation of the protective effect of NAC on $\mathrm{K}_{2} \mathrm{Cr}_{2} \mathrm{O}_{7}$-induced apoptosis. The levels of expression of poly (ADP-ribose) polymerase (PARP), cleaved-PARP, pro-caspase 3 , cleaved-caspase 3, Bax, Bcl-xL, cleaved-caspase 9 , and cleaved-caspase 8 were determined at different time-points of NAC treatment. Quantitative results of (B) PARP $(n=3)$, (C) caspase $3(n=3)$, (D) Bax/Bcl-xL ratio $(n=3)$, (E) cleaved-caspase $9(n=3)$, and (F) cleaved-caspase $8(n=3)$ are shown. Data in the bar plots are presented as mean $\pm \mathrm{SD} .{ }^{*} P<0.05,{ }^{* *} P<0.01,{ }^{* * *} P<0.001$ when compared with $10 \mu \mathrm{M} \mathrm{K}_{2} \mathrm{Cr}_{2} \mathrm{O}_{7}$-treatment group. 


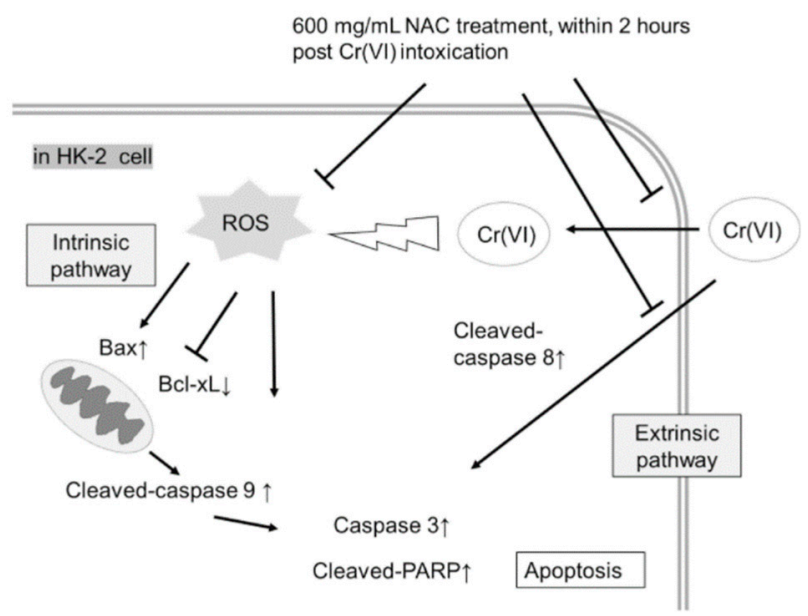

Figure 6. Proposed scheme of NAC treatment. Cr(VI) exposure induced ROS and then activated apoptotic pathways in human epithelial renal proximal tubule cells. In addition, extrinsic pathways were induced by an unknown mechanism. NAC treatment within $2 \mathrm{~h}$ post $\mathrm{Cr}(\mathrm{VI})$-induced toxicity effectively rescued cells from apoptosis.

\section{Discussion}

Chromium induces the production of free radicals by a Fenton-type reaction, a Haber-Weiss reaction, or by reacting directly with cellular molecules, triggering multiple apoptosis-signaling pathways in several cell types [27-29]. A chromium concentration in of $10 \mathrm{mg} / \mathrm{L}$ or higher in the blood is considered to be a lethal dose for humans [30]. Other reports described that a chromium blood concentration of $3.4 \mathrm{mg} / \mathrm{L}$ induced acute renal dysfunction without leading to a lethal result [31]. In this study, HK-2 cells exposed to $10 \mu \mathrm{M}(2.95 \mathrm{mg} / \mathrm{L})$ of $\mathrm{Cr}(\mathrm{VI})$ were at an increased likelihood of cell death, with higher intracellular ROS levels detected (Figures 1 and 2). Our results further demonstrated that co-administration of NAC and $\mathrm{Cr}(\mathrm{VI})$ resulted in the suppression of intracellular ROS production, suggesting a satisfactory efficacy of NAC in the prevention of chromium-induced renal damage by means of its chelating effect $[24,32,33]$.

NAC has been widely used in renal protection against oxidative stress injury, such as ischemia-reperfusion injury [34,35], nephrotoxin-induced injury [36-38], and chronic kidney disease [39], thus suggesting that it is a safe and effective treatment for oxidative stress injuries. The optimal dose and tolerable lag period of NAC treatment was evaluated in HK-2 cells. Our results revealed that a supplement with $600 \mu \mathrm{g} / \mathrm{mL}$ NAC did not induce cytotoxicity and significantly inhibited intracellular ROS in human epithelial renal proximal tubule cells. In addition, NAC treatment significantly enhanced cell viability when cells were treated with $600 \mu \mathrm{g} / \mathrm{mL}$ NAC within $2 \mathrm{~h}$ of $\mathrm{Cr}(\mathrm{VI})$-induced toxicity (Figures 3 and 4 ). In a $\mathrm{Cr}(\mathrm{VI})$-treated mice model, treatment with NAC $(200 \mathrm{mg} / \mathrm{kg}$, intraperitoneal injection) an hour before $\mathrm{Cr}(\mathrm{VI})(20 \mathrm{mg} / \mathrm{kg})$ treatment and an hour after $\mathrm{Cr}(\mathrm{VI})$ toxicity provided beneficial effects in the liver and kidney tissue [25]. Clinical data previously showed that administration of $150 \mathrm{mg} / \mathrm{kg}$ of NAC for the treatment of acetaminophen overdose led to a mean maximum concentration of NAC of $554 \mu \mathrm{g} / \mathrm{mL}$ in plasma [40]. Based on the above evidence, $150-200 \mathrm{mg} / \mathrm{kg}$ NAC may be an optimal range of dosage in the treatment of $\mathrm{Cr}(\mathrm{VI})$-induced renal toxicity. Moreover, our results suggested that the tolerable time gap for NAC treatment is less than $2 \mathrm{~h}$. This finding may explain why a supplement of $50 \mathrm{mg} / \mathrm{kg}$ NAC after $6 \mathrm{~h}$ of Cr exposure could not prevent the development of life-threatening phenomena [41].

Current evidence suggests that $\mathrm{Cr}(\mathrm{VI})$-induced toxicity brings about cell apoptosis, mainly via intrinsic mitochondrial pathways but not extrinsic pathways, in several types of cells, including human lung tumor cells, lymphoma cells, anterior pituitary cells, hepatocyte cells, and colon carcinoma cells $[15,42,43]$. The intrinsic pathway is regulated by pro-apoptotic and anti-apoptotic proteins, such as Bax and Bcl-xL, respectively [44]. In contrast, caspase 8 plays a critical role in the extrinsic apoptotic 
signaling pathway [44]. Figure 5 displays our results demonstrating that NAC treatment within $2 \mathrm{~h}$ of $\mathrm{Cr}(\mathrm{VI})$-induced toxicity significantly decreased the ratio of $\mathrm{Bax} / \mathrm{Bcl}-\mathrm{xL}$ and the activation of caspase 9, which implied that the intrinsic apoptosis pathways were inhibited. In addition, delayed treatment with NAC, up to $8 \mathrm{~h}$, could only block the extrinsic pathway (cleaved-caspase 8 ). These results implied that $\mathrm{Cr}(\mathrm{VI})$ first triggers the intrinsic pathways, followed thereafter by the extrinsic pathways. Because our results demonstrated that HK-2 cells had to be treated with NAC within $2 \mathrm{~h}$ of $\mathrm{Cr}(\mathrm{VI})$-induced toxicity to reduce damage, we inferred that the therapeutic effect of NAC was mainly dependent on inhibition of intrinsic pathways in these cells. We supposed that the delay and inhibition of only the extrinsic pathways may be insufficient to block apoptosis. Further experimental evidence is needed to support this hypothesis. For example, z-IETD-FMK, a specific caspase-8 inhibitor, can be used to investigate the importance of extrinsic pathways in $\mathrm{Cr}(\mathrm{VI})$-induced cell death or NAC protection. We will perform these experiments in the future.

It is interesting to note that the Bax level in NAC increased when compared to untreated cells (Figure 5A). A high concentration ( 2 to $5 \mathrm{mM}$ ) of NAC treatment can induce apoptosis in some types of cells, such as vascular smooth muscle cells and myoblastic cells, alongside an increase in Bax expression levels $[45,46]$. In this study, the cell viability of HK-2 was not significantly affected after NAC treatments at concentrations of $100 \mu \mathrm{g} / \mathrm{mL}$ to $1000 \mu \mathrm{g} / \mathrm{mL}(0.613$ to $6.13 \mathrm{mM})$. Therefore, the current data suggest that Bax was also induced by NAC, but cell viability was not affected. The role of Bax in NAC-treated renal cells needs to be further investigated in the future.

There are some limitations to this study. The optimal doses of NAC and periods of delayed NAC treatment were evaluated in a single cell line in vitro, but not evaluated in vivo. Therefore, further detailed studies on this treatment are still required in the future.

\section{Conclusions}

Our observations are the first to describe the optimal timing and dose of NAC in the protection of human renal proximal tubular cells from $\mathrm{Cr}(\mathrm{VI})$-induced cell death. Our results imply that the strategy of NAC treatment could be applied in clinical practice, because inhibition of apoptosis might rescue renal function. These results could help in the design of an NAC treatment strategy, which could provide novel evidence to assist emergency physicians in the treatment of curable, but not lethal, chromium toxicity.

\section{Materials and Methods}

\subsection{HK-2 Cell Culture}

HK-2 cells (ATCC CRL-2190) derived from an adult human normal kidney were characterized as a proximal tubular epithelial renal cell line [47]. HK-2 was purchased from American Type Culture Collection (ATCC) and maintained in keratinocyte-serum-free medium (K-SFM) supplemented with bovine pituitary extract (BPE), human recombinant epidermal growth factor (EGF), and $1 \%$ penicillin-streptomycin (Life Technologies, CA, USA). Cells were incubated at $37^{\circ} \mathrm{C}$ in a humidified atmosphere containing $95 \%$ air and $5 \% \mathrm{CO}_{2}$.

\subsection{MTT Assay for Cell Viability}

To determine the toxicity of NAC, $1 \times 10^{4} \mathrm{HK}-2$ cells were treated with various concentrations (100, 300, 600, and $1000 \mu \mathrm{g} / \mathrm{mL}$ ) of NAC (A8199, Sigma-Aldrich, Saint Louis, USA) for $24 \mathrm{~h}$. To determine the protective effect of NAC, $1 \times 10^{4} \mathrm{HK}-2$ cells were treated with $10 \mu \mathrm{M} \mathrm{K} \mathrm{K}_{2} \mathrm{Cr}_{2} \mathrm{O}_{7}$ and various concentrations of NAC $(100,300,600$, and $1000 \mu \mathrm{g} / \mathrm{mL})$ at different time-points after chromium exposure $(0,1,2,4$, and $8 \mathrm{~h})$. After incubating further for $24 \mathrm{~h}$, cell viabilities were directly examined by an inverted microscope, Eclipse Ti-U (Nikon, Tokyo, Japan), under 400× $g$ magnification, and indirectly assayed using a 3-(4,5-dimethylthiazol-2-yl)-2,5-diphenyl-tetrazolium bromide (MTT) kit 
(Sigma-Aldrich, Schnelldorf, Germany), according to the manufacturer's instruction. The absorbance at A570 $\mathrm{nm}$ was determined by an ELISA reader (Multiskan EX, Labsystems, MA, USA).

\subsection{Annexin V/Propidium Iodide (PI) Staining}

The apoptosis phenotype was analyzed by fluorescein (FITC)-conjugated Annexin V and a propidium iodide detection kit (BD Technologies, New Jersey, USA). HK-2 $1 \times 10^{6}$ cells were seeded into $10 \mathrm{~cm}$ culture dishes with serum free Dulbecco's Modified Eagle's Medium (DMEM) (Sigma-Aldrich, Saint Louis, USA). $\mathrm{K}_{2} \mathrm{Cr}_{2} \mathrm{O}_{7}(10 \mu \mathrm{M})$ was added to the cells and subsequently cultured for 24,30 , and $45 \mathrm{~h}$. After removing the supernatant, which included the dead/suspended cells, attached cells were harvested, washed with cold PBS, suspended in $100 \mu \mathrm{L}$ Annexin V-FITC binding buffer and $5 \mu \mathrm{L}$ Annexin V-FITC or $5 \mu \mathrm{L}$ propidium iodide (PI), and incubated at room temperature in the dark for $15 \mathrm{~min}$. The samples were analyzed via a Partec Cyflow machine (Sysmex Partec GmbH, Gorlitz, Germany). The results were determined according to a four-quadrant diagram and analyzed using FlowJo software (Leonard Herzenberg, NY, USA).

\subsection{Oxidative Stress Assays}

The production of reactive oxygen species (ROS) as a result of chromium toxicity was detected by flow cytometry. HK-2 cells $\left(1 \times 10^{6}\right)$ were incubated in $10 \mathrm{~cm}$ culture dishes with $5 \mu \mathrm{M}$ $2^{\prime} 7^{\prime}$-dichlorofluorescein diacetate (H2DCFDA) (Sigma-Aldrich, Schnelldorf, Germany) at $37^{\circ} \mathrm{C}$ for $30 \mathrm{~min}$. After centrifugation and washing with PBS, HK-2 cells were exposed to $10 \mu \mathrm{M} \mathrm{K}{ }_{2} \mathrm{Cr}_{2} \mathrm{O}_{7}$ and supplemented with various concentrations of NAC $(300 \mu \mathrm{g} / \mathrm{mL}, 600 \mu \mathrm{g} / \mathrm{mL}$, and $1000 \mu \mathrm{g} / \mathrm{mL})$ in triplicate. Following 30 min of incubation, fluorescence intensity which correlates with hydroxyl radical concentration was detected by Partec CyFlow (Partec, Münster, Germany). Data were analyzed by FCS Express 4 Flow Cytometry (De Novo, Los Angeles, CA, USA). All procedures were performed on ice with protection from light.

\subsection{Apoptotic Assay by Western Blot Analysis}

HK-2 cells $\left(10^{6}\right)$ were seeded into $10 \mathrm{~cm}$ culture dishes and cultured with K-SFM and supplemented until 80\% confluence was reached. Cells were washed with PBS twice and K-SFM was replaced with serum-free DMEM. After treatment with $10 \mu \mathrm{M} \mathrm{K}_{2} \mathrm{Cr}_{2} \mathrm{O}_{7}, 600 \mu \mathrm{g} / \mathrm{mL}$ NAC was supplemented at 0, $2,4,6$, and $8 \mathrm{~h}$, and the cells were further incubated for $36 \mathrm{~h}$. After washing with cold PBS, cells were supplemented with $200 \mu \mathrm{L}$ radioimmunoprecipitation (RIPA) lysis buffer (Amresco, Ohio, USA) containing $1 \%$ proteinase inhibitor and kept on ice for $20 \mathrm{~min}$. Total cellular proteins were extracted by gently vortexing and centrifuging at $16,000 \mathrm{~g}$ for $20 \mathrm{~min}$ at $4{ }^{\circ} \mathrm{C}$. To extract the cytosolic protein fraction, the Nuclear Protein Isolation-Translocation Assay Kit (FIVEphoton Biochemical, San Diego, USA) was used. Proteins were quantified using Bio-Rad protein assay kit (Bio-Rad, CA, USA). Later, total proteins $(40 \mu \mathrm{g})$ were mixed with sample buffer ( $5 \%$ mercaptoethanol, $0.02 \%$ bromophenol blue, $30 \%$ glycerol, $10 \%$ sodium dodecyl sulfate (SDS), $250 \mathrm{mM} \mathrm{pH} \mathrm{6.8)} \mathrm{and} \mathrm{then} \mathrm{boiled} \mathrm{for} 5-10 \mathrm{~min}$ at $95{ }^{\circ} \mathrm{C}$. The mixture was separated on a $10 \%$ SDS-polyacrylamide gel and electrophoresis was performed at $100 \mathrm{~V}$ for $1 \mathrm{~h}$. The separated proteins were transferred to a Hybond-P polyvinylidene difluoride (PVDF) membrane (Amersham Biosciences, UK) and blocked with $3 \%$ bovine serum albumin (BSA) in Tris-buffered saline containing Tween 20 (TBST) for $1 \mathrm{~h}$. Apoptosis-related proteins were detected by a 1:1000 dilution of commercial monoclonal antibodies, including primary antibodies for the detection of anti-poly (ADP-ribose) polymerase (PARP) (1:1000, Cell Signaling Technology, MA, USA), pro-caspase 3 (1:1000, Millpore, Temecula, CA, USA), cleaved-caspase 3 (1:,000, Sigma, Temecula, CA, USA), Bcl-xL (1:1000, Biolegend, San Diego, CA, USA), Bax (1:1000, Cell Signaling Technology, MA, USA), cleaved-caspase 9 (1:1000, Cell Signaling Technology, MA, USA), and cleaved-caspase 8 (1:1000, Cell Signaling Technology, MA, USA) overnight at $4{ }^{\circ} \mathrm{C}$. This was followed by a 1:5000 dilution of goat anti-mouse IgG- horseradish peroxidase (HRP) conjugated antibody (Biolegend, San Diego, USA) or a 1:10,000 dilution goat anti-rabbit IgG-HRP conjugated antibody (Biolegend, san Diego, USA) at room 
temperature for $1 \mathrm{~h}$. The internal control, $\beta$-actin (Chemicon, CA, USA), was assayed using a 1:1000 dilution of primary antibody and detected by the same secondary antibody described above. Target proteins were visualized with Clarity ${ }^{\mathrm{TM}}$ Western enhanced luminol-based chemiluminescent substrate (ECL) Substrate (Bio-Rad, CA, USA) and HyBlot CL film (Denville Scientific Inc, NJ, USA). The density of each band was quantified with ImageJ software (NIH, Maryland, USA).

\subsection{Statistical Analysis}

The results of at least three independent experiments were expressed as mean \pm SD. Data were analyzed using ANOVA by SPSS20 software (SPSS, Chicago, USA). Scheffe's test was used for post-hoc analysis to compare all pairs of the groups in the ANOVA test. The level of significance was set at $P<0.05$.

Author Contributions: I-J.Y. and C.-Y.P. conceived and designed the experiments; P.-L.W., F.-W.C., and Y.-L.S. performed the experiments; T.-Y.W, J.-C.L., T.-J.L., J.-S.C., M.-C.Y., and Y.-H.L analyzed the data; I-J.Y., J.-C.L., J.-S.C., and C.-Y.P. contributed reagents/materials/analysis tools; all authors contributed to the editing and final approval of the paper.

Funding: This study was supported by grants from the Kaohsiung Medical University Hospital (KMUH103-3M52).

Conflicts of Interest: The authors declare no conflict of interest.

\section{References}

1. Stohs, S.J.; Bagchi, D. Oxidative mechanisms in the toxicity of metal ions. Free Radic. Biol. Med. 1995, 18, 321-336. [CrossRef]

2. Wang, X.F.; Xing, M.L.; Shen, Y.; Zhu, X.; Xu, L.H. Oral administration of $\mathrm{Cr}(\mathrm{VI})$ induced oxidative stress, DNA damage and apoptotic cell death in mice. Toxicology 2006, 228, 16-23. [CrossRef] [PubMed]

3. Sun, H.; Brocato, J.; Costa, M. Oral Chromium Exposure and Toxicity. Curr. Environ. Health Rep. 2015, 2, 295-303. [CrossRef] [PubMed]

4. Sharma, P.; Bihari, V.; Agarwal, S.K.; Verma, V.; Kesavachandran, C.N.; Pangtey, B.S.; Mathur, N.; Singh, K.P.; Srivastava, M.; Goel, S.K. Groundwater contaminated with hexavalent chromium [Cr (VI)]: A health survey and clinical examination of community inhabitants (Kanpur, India). PloS ONE 2012, 7, e47877. [CrossRef] [PubMed]

5. Zhitkovich, A. Chromium in drinking water: Sources, metabolism, and cancer risks. Chem. Res. Toxicol. 2011, 24, 1617-1629. [CrossRef] [PubMed]

6. Snyder, R.D. Role of active oxygen species in metal-induced DNA strand breakage in human diploid fibroblasts. Mutat. Res. 1988, 193, 237-246. [CrossRef]

7. Wakeman, T.P.; Kim, W.J.; Callens, S.; Chiu, A.; Brown, K.D.; Xu, B. The ATM-SMC1 pathway is essential for activation of the chromium [VI]-induced S-phase checkpoint. Mutat. Res. 2004, 554, 241-251. [CrossRef]

8. Ha, L.; Ceryak, S.; Patierno, S.R. Generation of S phase-dependent DNA double-strand breaks by Cr (VI) exposure: Involvement of ATM in Cr (VI) induction of gamma-H2AX. Carcinogenesis 2004, 25, 2265-2274. [CrossRef]

9. Shil, K.; Pal, S. Metabolic adaptability in hexavalent chromium-treated renal tissue: An in vivo study. Clin. Kidney J. 2018, 11, 222-229. [CrossRef]

10. Sanz, P.; Nogue, S.; Munne, P.; Torra, R.; Marques, F. Acute potassium dichromate poisoning. Hum. Exp. Toxicol. 1991, 10, 228-229. [CrossRef]

11. Ellis, E.N.; Brouhard, B.H.; Lynch, R.E.; Dawson, E.B.; Tisdell, R.; Nichols, M.M.; Ramirez, F. Effects of hemodialysis and dimercaprol in acute dichromate poisoning. J. Toxicol. Clin. Toxicol. 1982, 19, 249-258. [CrossRef] [PubMed]

12. Meert, K.L.; Ellis, J.; Aronow, R.; Perrin, E. Acute ammonium dichromate poisoning. Ann. Emerg. Med. 1994, 24, 748-750. [CrossRef]

13. Sunilkumar, M.N.; Ajith, T.A.; Parvathy, V.K. Acute ammonium dichromate poisoning in a 2 year-old child. Indian J. Crit. Care Med. 2014, 18, 757-758. [CrossRef] [PubMed]

14. Kaufman, D.B.; DiNicola, W.; McIntosh, R. Acute potassium dichromate poisoning. Treated by peritoneal dialysis. Am. J. Dis. Child. 1970, 119, 374-376. [CrossRef] [PubMed] 
15. Chiu, A.; Shi, X.L.; Lee, W.K.; Hill, R.; Wakeman, T.P.; Katz, A.; Xu, B.; Dalal, N.S.; Robertson, J.D.; Chen, C.; et al. Review of chromium (VI) apoptosis, cell-cycle-arrest, and carcinogenesis. J. Environ. Sci. Health C Environ. Carcinog. Ecotoxicol. Rev. 2010, 28, 188-230. [CrossRef] [PubMed]

16. Hu, G.; Zheng, P.; Feng, H.; Jia, G. Imbalance of oxidative and reductive species involved in chromium(VI)-induced toxic effects. React. Oxyg. Species 2017, 3, 1-11. [CrossRef]

17. Lin, T.J.; Huang, Y.L.; Chang, J.S.; Liu, K.T.; Yen, M.C.; Chen, F.W.; Shih, Y.L.; Jeo, J.C.; Huang, P.C.; Yeh, I.J. Optimal dosage and early intervention of L-ascorbic acid inhibiting $\mathrm{K} 2 \mathrm{Cr} 2 \mathrm{O} 7$-induced renal tubular cell damage. J. Trace Elem. Med. Biol. 2018, 48, 1-7. [CrossRef] [PubMed]

18. Cotgreave, I.A. N-acetylcysteine: Pharmacological considerations and experimental and clinical applications. Adv. Pharmacol. 1997, 38, 205-227. [PubMed]

19. Scholz, R.W.; Graham, K.S.; Gumpricht, E.; Reddy, C.C. Mechanism of interaction of vitamin-E and glutathione in the protection against membrane lipid-peroxidation. Ann. N. Y. Acad. Sci. 1989, 570, 514-517. [CrossRef]

20. Pompella, A.; Visvikis, A.; Paolicchi, A.; De Tata, V.; Casini, A.F. The changing faces of glutathione, a cellular protagonist. Biochem. Pharmacol. 2003, 66, 1499-1503. [CrossRef]

21. Quinteros, F.A.; Machiavelli, L.I.; Miler, E.A.; Cabilla, J.P.; Duvilanski, B.H. Mechanisms of chromium (VI)-induced apoptosis in anterior pituitary cells. Toxicology 2008, 249, 109-115. [CrossRef] [PubMed]

22. Saito, C.; Zwingmann, C.; Jaeschke, H. Novel mechanisms of protection against acetaminophen hepatotoxicity in mice by glutathione and N-acetylcysteine. Hepatology 2010, 51, 246-254. [CrossRef] [PubMed]

23. Louie, B.; Rajamahanty, S.; Pyo, P.; Choudhury, M.; Konno, S. Mode of cytotoxic action of nephrotoxic agents: Oxidative stress and glutathione-dependent enzyme. BJU Int. 2010, 105, 264-268. [CrossRef] [PubMed]

24. Blanusa, M.; Varnai, V.M.; Piasek, M.; Kostial, K. Chelators as antidotes of metal toxicity: Therapeutic and experimental aspects. Curr. Med. Chem. 2005, 12, 2771-2794. [CrossRef] [PubMed]

25. Boşgelmez, İ.I.; Güvendik, G. N-Acetyl-L-Cysteine Protects Liver and Kidney Against Chromium(VI)-Induced Oxidative Stress in Mice. Biol. Trace Elem. Res. 2017, 178, 44-53. [CrossRef] [PubMed]

26. Liu, K.J.; Shi, X. In vivo reduction of chromium (VI) and its related free radical generation. In Molecular Mechanisms of Metal Toxicity and Carcinogenesis; Springer: Boston, MA, USA, 2001; pp. 41-47.

27. Leonard, S.S.; Roberts, J.R.; Antonini, J.M.; Castranova, V.; Shi, X. PbCrO4 mediates cellular responses via reactive oxygen species. Mol. Cell. Biochem. 2004, 255, 171-179. [CrossRef]

28. Sinha, K.; Das, J.; Pal, P.B.; Sil, P.C. Oxidative stress: The mitochondria-dependent and mitochondriaindependent pathways of apoptosis. Arch. Toxicol. 2013, 87, 1157-1180. [CrossRef]

29. Redza-Dutordoir, M.; Averill-Bates, D.A. Activation of apoptosis signalling pathways by reactive oxygen species. Biochim. Biophys. Acta 2016, 1863, 2977-2992. [CrossRef]

30. Pedersen, R.S.; Morch, P.T. Chromic acid poisoning treated with acute hemodialysis. Nephron 1978, 22, 592-595. [CrossRef]

31. KhanSaif, R.; Aparna, Q.; Shahzad, S.; Haque, F. Chromium induced AKI: Case with protean implications. Ann. Trop. Med. Public Health 2014, 7, 136-138.

32. Karaytug, S.; Sevgiler, Y.; Karayakar, F. Comparison of the protective effects of antioxidant compounds in the liver and kidney of Cd- and Cr-exposed common carp. Environ. Toxicol. 2014, 29, 129-137. [CrossRef] [PubMed]

33. Banner, W., Jr.; Koch, M.; Capin, D.M.; Hopf, S.B.; Chang, S.; Tong, T.G. Experimental chelation therapy in chromium, lead, and boron intoxication with $\mathrm{N}$-acetylcysteine and other compounds. Toxicol. Appl. Pharmacol. 1986, 83, 142-147. [CrossRef]

34. Nitescu, N.; Ricksten, S.E.; Marcussen, N.; Haraldsson, B.; Nilsson, U.; Basu, S.; Guron, G. N-acetylcysteine attenuates kidney injury in rats subjected to renal ischaemia-reperfusion. Nephrol. Dial. Transplant. 2006, 21, 1240-1247. [CrossRef] [PubMed]

35. Dobashi, K.; Singh, I.; Orak, J.K.; Asayama, K.; Singh, A.K. Combination therapy of N-acetylcysteine, sodium nitroprusside and phosphoramidon attenuates ischemia-reperfusion injury in rat kidney. Mol. Cell. Biochem. 2002, 240, 9-17. [CrossRef] [PubMed]

36. Luo, J.; Tsuji, T.; Yasuda, H.; Sun, Y.; Fujigaki, Y.; Hishida, A. The molecular mechanisms of the attenuation of cisplatin-induced acute renal failure by $\mathrm{N}$-acetylcysteine in rats. Nephrol. Dial. Transplant. 2008, 23, 2198-2205. [PubMed] 
37. Kim, J.H.; Lee, S.S.; Jung, M.H.; Yeo, H.D.; Kim, H.J.; Yang, J.I.; Roh, G.S.; Chang, S.H.; Park, D.J. $\mathrm{N}$-acetylcysteine attenuates glycerol-induced acute kidney injury by regulating MAPKs and Bcl-2 family proteins. Nephrol. Dial. Transplant. 2010, 25, 1435-1443. [PubMed]

38. Fishman, A.I.; Alexander, B.; Eshghi, M.; Choudhury, M.; Konno, S. Nephrotoxin-induced renal cell injury involving biochemical alterations and its prevention with antioxidant. J. Clin. Med. Res. 2012, 4, 95-101. [CrossRef]

39. Shimizu, M.H.; Coimbra, T.M.; de Araujo, M.; Menezes, L.F.; Seguro, A.C. N-acetylcysteine attenuates the progression of chronic renal failure. Kidney Int. 2005, 68, 2208-2217.

40. Prescott, L.F.; Donovan, J.W.; Jarvie, D.R.; Proudfoot, A.T. The disposition and kinetics of intravenous $\mathrm{N}$-acetylcysteine in patients with paracetamol overdosage. Eur. J. Clin. Pharmacol. 1989, 37, 501-506. [CrossRef]

41. Lin, C.C.; Wu, M.L.; Yang, C.C.; Ger, J.; Tsai, W.J.; Deng, J.F. Acute severe chromium poisoning after dermal exposure to hexavalent chromium. J. Chin. Med. Assoc. 2009, 72, 219-221. [CrossRef]

42. Quinteros, F.A.; Poliandri, A.H.; Machiavelli, L.I.; Cabilla, J.P.; Duvilanski, B.H. In vivo and in vitro effects of chromium VI on anterior pituitary hormone release and cell viability. Toxicol. Appl. Pharmacol. 2007, 218, 79-87. [CrossRef] [PubMed]

43. Xiao, F.; Li, Y.; Dai, L.; Deng, Y.; Zou, Y.; Li, P.; Yang, Y.; Zhong, C. Hexavalent chromium targets mitochondrial respiratory chain complex I to induce reactive oxygen species-dependent caspase-3 activation in L-02 hepatocytes. Int. J. Mol. Med. 2012, 30, 629-635. [CrossRef] [PubMed]

44. Elmore, S. Apoptosis: A review of programmed cell death. Toxicol. Pathol. 2007, 35, 495-516. [CrossRef] [PubMed]

45. Rakshit, S.; Bagchi, J.; Mandal, L.; Paul, K.; Ganguly, D.; Bhattacharjee, S.; Bandyopadhyay, S.; Biswas, N.; Chaudhuri, U.; Ghosh, M.; et al. N-acetyl cysteine enhances imatinib-induced apoptosis of Bcr-Abl+ cells by endothelial nitric oxide synthase-mediated production of nitric oxide. Apoptosis 2009, 14, 298-308. [CrossRef] [PubMed]

46. Liu, Y.; Liu, K.; Wang, N.; Zhang, H. Nacetylcysteine induces apoptosis via the mitochondriadependent pathway but not via endoplasmic reticulum stress in H9c2 cells. Mol. Med. Rep. 2017, 16, 6626-6633. [CrossRef] [PubMed]

47. Ryan, M.J.; Johnson, G.; Kirk, J.; Fuerstenberg, S.M.; Zager, R.A.; Torok-Storb, B. HK-2: An immortalized proximal tubule epithelial cell line from normal adult human kidney. Kidney Int. 1994, 45, 48-57. [CrossRef] [PubMed]

(C) 2019 by the authors. Licensee MDPI, Basel, Switzerland. This article is an open access article distributed under the terms and conditions of the Creative Commons Attribution (CC BY) license (http://creativecommons.org/licenses/by/4.0/). 